\title{
Workability and compressive strength properties of normal weight concrete using high dosage of fly ash as cement replacement
}

\author{
S. A. Shaikuthali ${ }^{1} \cdot$ M. A. Mannan ${ }^{1} \cdot$ Eethar Thanon Dawood $^{2} @$ - D. C. L. Teo ${ }^{1} \cdot$ Raudhah Ahmadi $^{1} \cdot$ Idawati Ismail $^{1}$
}

Received: 14 February 2019/ Accepted: 3 September 2019

(c) Springer Nature Switzerland AG 2019

\begin{abstract}
This study evaluates the workability and compressive strength properties of normal weight concrete (NWC) using high dosage of fly ash cement replacement. The goal is to find the suitable mix proportion of G40 NWC and to study the slump-loss at different interval time with fly ash replacement up to $60 \%$. The strength properties of NWC were investigated using rebound hammer test as non-destructive and compressive strength test for verifying it. The acceptable mix proportion for fly ash replacement was then investigated using laboratory experiments. For strength properties of NWC, the samples were tested for 3, 7, 14 and 28 days. Results indicate that the inclusion of fly ash as partial cement replacement improves the workability of NWC concrete. The slump-loss of NWC with fly ash increases and it delays the setting time of fresh concrete. The strength of concrete reduces with an increment of fly ash. The strength measured using non-destructive test is lower when compared to compressive strength test. The results demonstrate that the replacement of cement with fly ash in concrete is beneficial and the targeted strength of concrete will achieve with time.
\end{abstract}

Keywords Slump-loss $\cdot$ Non-destructive strength test $\cdot$ Fly ash $\cdot$ Compressive strength test

\section{Introduction}

As the demand for infrastructure development increases, it also increases the utilization of concrete in construction industries. The high demand in concrete productions requires a high amount of cement. However, the cement industry has huge effects on the environment, economy and also energy consumption [1]. With the aid of technological advances, the concrete industry constantly looking for supplementary cementitious material in producing value added products and also reducing the solid waste disposal problem [2].

Fly ash is one of the most commonly used supplementary cementing material as it is a waste product resulting from

Eethar Thanon Dawood

eethar2005@yahoo.com

M. A. Mannan

mannan@unimas.my

1 Department of Civil Engineering, Faculty of Engineering, Universiti Malaysia Sarawak, Sarawak, Malaysia

2 Department of Building and Construction Engineering, Technical College of Mosul, Northern Technical University, Mosul, Iraq the combustion of coal. It is being utilized as a pozzolanic material in concrete because of its ability in improving the concrete properties both in the fresh and hardened state [3]. Fly ash is abundantly available in West Malaysia and its production increasing year by year. For example, in Tanjung Bin Power Station at Pontian Johor, about 1620 tonnes of fly ash is being produced from 18,000 tonnes of coal combustion in a day [4]. The production of fly ash is high in Tanjung Bin Power Station due to its electricity generation of $2100 \mathrm{MW}$ which is being generated from three stations. However, in East Malaysia like Sarawak Sejingkat Thermal Power Station, it produces about $5 \%$ of fly ash from one million tonnes of coal combustion annually for the electricity generation of $180 \mathrm{MW}$.

The inclusion of fly ash in concrete imparts several benefits to the environment and improves the properties of concrete like workability, compressive strength, and durability. Besides, it also contributes to lower heat evolution, lower water demand and reduced the bleeding in concrete [5-7]. Most of the researchers deduced that the replacement of fly ash by $15-35 \%$ of the total weight of cementitious material indicates the good result in concrete properties.

The abundant production of fly ash will lead to environmental issues like landfills. The percentage of fly ash as 